\title{
Prevalence and distribution of resistance and enterotoxins/enterotoxin-like genes in different clinical isolates of coagulase-negative Staphylococcus
}

\author{
Mona Nasaj ${ }^{1}$, Zahra Saeidi ${ }^{1}$, Hamed Tahmasebi $^{2}$, Sanaz Dehbashi ${ }^{1}$ and Mohammad Reza Arabestani ${ }^{1,3^{*} \text { (D) }}$
}

\begin{abstract}
Background: Coagulase-negative staphylococcus (CONS) is considered to be the major reservoirs for genes facilitating the evolution of $\mathrm{S}$. aureus as a successful pathogen. The present study aimed to determine the occurrence of genes conferring resistance to fluoroquinolone, determining of the prevalence of insertion sequence elements IS256, IS257 and different superantigens (SAgs) among CoNS isolates obtained from various clinical sources.

Materials and methods: The current study conducted on a total of the 91 CoNS species recovered from clinical specimens in Hamadan hospitals in western Iran in 2017-2019. The antimicrobial susceptibility testing was performed using disk diffusion method and the presence of the IS256 and IS257, genes conferring resistance to fluoroquinolone and enterotoxins/enterotoxin-like encoding genes were investigated by polymerase chain reaction (PCR) method.

Results: Among genes encoding classic enterotoxins, sec was the most frequent which was carried by $48.4 \%$ of the 91 isolates, followed by seb in $27.5 \%$ of the isolates. None of the CoNS isolates was found to be positive to enterotoxinlike encoding genes. In 11(12\%) of all isolates that were phenotypically resistant to levofloxacin, 9 isolates (81.8\%) were positive for gyrB, 8 isolates (72.7\%) were positive for $g y r A, 8$ isolates (72.7\%) harbored grlB and 7 isolates (63.6\%) were found to carry grlA. The IS256 and IS257 were identified in 31.8\% and $74.7 \%$ of the isolates, respectively. The results of statistical analysis showed a significant association between the occurrence of staphylococcal enterotoxins (SEs) encoding genes and antimicrobial resistance.

Conclusion: Antimicrobial resistant determinants and SEs are co-present in clinical CoNS isolates that confer selective advantage for colonization and survival in hospital settings. The coexistence of insertion elements and antibiotic resistance indicate their role in pathogenesis and infectious diseases.
\end{abstract}

Keywords: Coagulase-negative Staphylococcus, Superantigenes, Antibiotic resistance

\section{Background}

Coagulase-negative staphylococci (CoNS) serve as an important reservoir of antimicrobial resistance genes which can transmit between staphylococcal species or

\footnotetext{
*Correspondence: mohammad.arabestani@gmail.com

${ }^{3}$ Nutrition Research Center, Hamadan University of Medical Sciences, Hamadan, IR, Iran

Full list of author information is available at the end of the article
}

even other bacterial genera, but they have been implicated in rare cases of food poisoning [1,2]. Among CoNS species, S. epidermidis, S. hominis and S. haemolyticus are often developed to be resistant to multiple antibiotics [3]. Staphylococcal exotoxins have been divided into three groups of Staphylococcal heat-stable enterotoxins (SEs), responsible for the pathogenesis of Staphylococcal food poisoning (SFP), exfoliative toxins (ETs) and toxic shock 
syndrome toxin 1 (TSST-1), causative agents of scalded skin syndrome and toxic shock syndrome, respectively [4]. Besides coagulase-positive staphylococci (CoPS), it is recognized that CoNS species are also capable of producing enterotoxins and associated with food poisoning outbreaks [5]. Several SEs are classified as SE-like (SEl) toxins due to the fact that they still have not been tested for emetic activity or lack the emetic properties [6]. Various types of classical SEs including SEA, SEB, SEC1, SEC2, SEC3, SED, SEE and SEH on the basis of their antigenicities are currently described $[7,8]$. In addition to classical SEs, 16 new types of SEs (SEG, SEH, SEI, SER, SES, SET) and SEls (SEIJ, SEIK, SEIL, SEIM, SEIN, SEIO, SEIP, SEIQ, SEIU and SEIV) have been reported [6]. SEs are extracellular protein toxins with low molecular weight $(26.900-29.600 \mathrm{KD})[8,9]$. They are heat resistant and retain their biological activity after treatment with majority of proteolytic enzymes [10]. SEs as well as toxic shock syndrome toxin-1(TSST-1) are belonging to the pyrogenic toxin superantigen family of exotoxins (PTSAgs) [11]. Rate of nosocomial infections (NIs) and antibiotics resistance is high in Iranian hospital. The increasing rate of NIs causes more antibiotics usage which leads to economic burden, and as a final result, the increases rates of morbidity and mortality. It had reported that the most prevalent blood stream and urinary tract infections pathogens were CoNS and E. coli, respectively. The highest resistance rate of CoNS and E. coli was against Penicillin (91.1\%) and Nalidixic acid (57.7\%). The most used invasive devices were intravenous canola $(84.4 \%)$ and urinary indwelling catheter (81.7\%), and patients which had invasive devices treatments showed higher rates of antibiotic resistance [12]. Antimicrobial drug resistance in CoNS is increasing which led to serious problems for therapeutic options [13]. CoNS acts as large reservoir of mobile genetic elements, which confer resistance to B-lactams, aminoglycosides, quinolones, macrolides, and tetracyclines [13]. Fluoroquinolones are potent, broad-spectrum agents that were largely developed for the treatment of a wide range of infections due to Gram-positive and Gram-negative pathogenic bacteria [14]. The efficacy of more recent fluoroquinolones including levofloxacin, trovafloxacin, sparfloxacin, moxifloxacin, grepafloxacin and gatifloxacin have been confirmed for the treatment of various infections due to Gram-positive cocci [15]. The fluoroquinolones block activity of essential bacterial enzymes DNA gyrase and DNA topoisomerase IV, which involved in DNA replication [14]. GyrA and GyrB are the corresponding subunits of DNA gyrase, encoded by the gyrA and gyrB genes [16].Topoisomerase IV composed of ParC and ParE subunits (often referred as GrlA and GrlB in Staphylococcus aureus), encoded by $\mathrm{grlA}$ and $\mathrm{grlB}$ genes [14, 17]. Mechanisms of microbial resistance to fluoroquinolone include one or combination of five main bacterial mechanisms: alterations in the drug target, alteration in the cell permeability, quinolone-modifying enzymes, drug efflux pumps or gyrase protecting proteins $[14,15]$. To our knowledge, this is the first report in literature describing the occurrence rate of SAgs genes among human CoNS isolates. Regarding to the impacting of antibiotic resistance and toxins in pathogenicity of CoNS isolates as well as due to association between the occurrence of insertion sequence elements IS256 and IS257 with antimicrobial drug resistance and pathogenesis, the current study aimed at assessing the prevalence of SEs and TSST-1 toxins, ISs, antibiotic resistance trends and the quinolone resistance determining regions (QRDRs) of gyrA, gyrB, grlA and grlB genes in CoNS thriving in various types of clinical specimens.

\section{Materials and methods Identification of CoNS isolates}

A total of the 91 CoNS isolates were collected from various clinical specimens submitted to three teaching hospitals (including Beheshti, Besat, and Farshchian Hospitals) located in Hamedan, Iran, from September 2017 to November 2018. The origins of the isolates were as follows: blood, urine, catheters, and wounds. The included criteria were all patients with: (i) at least one positive blood culture for CoNS (ii) a central line in place for at least $48 \mathrm{~h}$ prior to a first positive blood culture (iii) who were treated with either linezolid, vancomycin or other antibiotics, methicillin-resistant and susceptible CoNS. The criteria for Exclusion were patients who transferred to other hospitals during treatment, as we could not assess outcomes such as recurrence or mortality. Staphylococcus aureus, Duplicate samples of same patients.

This study was approved by the ethics committee of the Hamadan University of Medical Sciences (Code No: IR.UMSHA.REC.1396.827).

\section{DNA extraction from isolates}

The plasmid DNA Extraction Mini Kit (Favorgen, Taiwan) and Plasmid Extraction Kit (Sinaclon, Iran) were used for plasmid DNA extraction according to the manufacturer's recommendations $[18,19]$. CoNS Chromosomal DNA was extracted by boiling method [20]. Quality of extracted DNA was assessed by the Nanodrop ND-1000 (Nanodrop Technologies, Inc., Wilmington, DE, USA).

\section{Antibiotic susceptibility testing}

The phenotypic antimicrobial susceptibility testing of various CoNS species was evaluated using a panel of 11 commercial antibiotic discs which belonged to various classes of antimicrobial agents. Disk agar diffusion 
(DAD) method was conducted according to the Clinical and Laboratory Standards Institute (CLSI) guidelines [21]. The antimicrobial agents used in current study were as follows: chloramphenicol $(30 \mu \mathrm{g})$, cefoxitin $(30 \mu \mathrm{g})$, clindamycin $(2 \mu \mathrm{g})$, doxycycline $(30 \mu \mathrm{g})$, erythromycin $(15 \mu \mathrm{g})$, gentamicin $(10 \mu \mathrm{g})$, levofloxacin $(5 \mu \mathrm{g})$, novobiocin $(5 \mu \mathrm{g})$, rifampicin $(5 \mu \mathrm{g})$, trimethoprim-sulfamethoxazole $(25 \mu \mathrm{g})$ and vancomycin $(30 \mu \mathrm{g})$ (MAST, Merseyside, UK). S. aureus ATCC33591 was used as a quality control.

\section{Detection of SEs and TSST 1 encoding genes}

Multiplex PCR was used to analyze the following genes: sea, seb, sec, sed, see, seg, seh, sei, selj, selm, seln, selo, selk, sell, selp, selq, selr, selu and tsst. Multiplex PCR method was performed using five different sets of oligonucleotide primer mixtures (Set 1: sea, seb, sec; Set 2: sed, see, seg, seh; Set 3: sei, selj, selm, seln; Set4:, selk, sell, selq, tsst; Set 5: selo, selp, selr, selu). PCR amplifications were carried out in $25 \mu \mathrm{L}$ volumes, containing $2 \mu \mathrm{L}$ template DNA, 1 $\mu \mathrm{L}$ of each forward primer, $1 \mu \mathrm{L}$ of each reverse primer, $7 \mu \mathrm{L}$ (Sets 2, 3, 4, and 5) and $9 \mu \mathrm{L}$ (Set 1) of sterile double distilled water and $8 \mu \mathrm{L}$ of $2 \times$ Taq Premix-Master mix (Parstous Biotech Co, Iran). The primers used to amplify SEs and TSST-1 encoding genes are listed in Table 1 [22-24]. Each PCR amplification reaction was performed using a Bio-Rad thermocycler (Bio-Rad, USA) with the following cycles: initial denaturation for $5 \mathrm{~min}$ at $95{ }^{\circ} \mathrm{C}$

Table 1 Primers used in this study

\begin{tabular}{|c|c|c|c|}
\hline Gene targets & Primer sequences $\left(5^{\prime}\right.$ to $\left.3^{\prime}\right)$ & Amplicon size (bp) & References \\
\hline sea & $\begin{array}{l}\text { F:TTGGAAACGGTTAAAACGAA } \\
\text { R: GAACCTTCCCATCAAAAACA }\end{array}$ & 120 & [22] \\
\hline seb & $\begin{array}{l}\text { F: TCGCATCAAACTGACAAACG } \\
\text { R: GCAGGTACTCTATAAGTGCC }\end{array}$ & 478 & [22] \\
\hline $\mathrm{sec}$ & $\begin{array}{l}\text { F: GACATAAAAGCTAGGAATTT } \\
\text { R: AAATCGGATTAACATTATCC }\end{array}$ & 257 & [22] \\
\hline sed & $\begin{array}{l}\text { F: CTAGTTTGGTAATATCTCCT } \\
\text { R: TAATGCTATATCTTATAGGG }\end{array}$ & 317 & [22] \\
\hline see & $\begin{array}{l}\text { F:TAGATAAAGTTAAAACAAGC } \\
\text { R:TAACTTACCGTGGACCCTTC }\end{array}$ & 170 & [22] \\
\hline seg & $\begin{array}{l}\text { F:TGCTATCGACACACTACAACC } \\
\text { R: CCAGATTCAAATGCAGAACC }\end{array}$ & 704 & [22] \\
\hline seh & $\begin{array}{l}\text { F: CGAAAGCAGAAGATTTACACG } \\
\text { R: GACCTTTACTTATTTCGCTGTC }\end{array}$ & 495 & [22] \\
\hline sei & $\begin{array}{l}\text { F: GACAACAAAACTGTCGAAACTG } \\
\text { R: CCATATTCTTTGCCTTTACCAG }\end{array}$ & 630 & [22] \\
\hline selj & $\begin{array}{l}\text { F: CAGCGATAGCAAAAATGAAACA } \\
\text { R:TCTAGCGGAACAACAGTTCTGA }\end{array}$ & 426 & [22] \\
\hline selm & $\begin{array}{l}\text { F: CCAATTGAAGACCACCAAAG } \\
\text { R: CTTGTCCTGTTCCAGTATCA }\end{array}$ & 517 & [22] \\
\hline seln & $\begin{array}{l}\text { F: ATTGTTCTACATAGCTGCAA } \\
\text { R: TTGAAAAAACTCTGCTCCCA }\end{array}$ & 682 & {$[22]$} \\
\hline selo & $\begin{array}{l}\text { F: AGTCAAGTGTAGACCCTATT } \\
\text { R:TATGCTCCGAATGAGAATGA }\end{array}$ & 534 & [22] \\
\hline selk & $\begin{array}{l}\text { F: TAGGTGTCTCTAATAATGCCA } \\
\text { R:TAGATATTCGTTAGTAGCTG }\end{array}$ & 293 & [23] \\
\hline sell & $\begin{array}{l}\text { F:TAACGGCGATGTAGGTCCAGG } \\
\text { R: CATCTATTTCTTGTGCGGTAAC }\end{array}$ & 383 & [23] \\
\hline selp & $\begin{array}{l}\text { F: TGATTTATTAGTAGACCTTGG } \\
\text { R: ATAACCAACCGAATCACCAG }\end{array}$ & 396 & [23] \\
\hline selr & $\begin{array}{l}\text { F: GGATAAAGCGGTAATAGCAG } \\
\text { R: GTATTCCAAACACATCTAAC }\end{array}$ & 166 & [23] \\
\hline selu & $\begin{array}{l}\text { F: AATGGCTCTAAAATTGATGG } \\
\text { R: ATTTGATTTCCATCATGCTC }\end{array}$ & 215 & [24] \\
\hline sela & $\begin{array}{l}\text { F: GGAAAATACACTTTATATTCACAGTTTCA } \\
\text { R: ATTTATTCAGTTTTCTCATATGAAATCTC }\end{array}$ & 539 & [24] \\
\hline tsst & $\begin{array}{l}\text { F: AAGCCCTTTGTTGCTTGCG } \\
\text { R: ATCGAACTTTGGCCCATACTTT }\end{array}$ & 447 & [23] \\
\hline
\end{tabular}


and then 35 cycles at $95^{\circ} \mathrm{C}$ for $1 \mathrm{~min}$ (denaturation), $52^{\circ} \mathrm{C}$ for $1 \mathrm{~min}$ (annealing) and $72^{\circ} \mathrm{C}$ for $2 \mathrm{~min}$ (extension) and final extension was performed at $72{ }^{\circ} \mathrm{C}$ for $7 \mathrm{~min}$. All PCR products were analyzed by electrophoresis for $50 \mathrm{~min}$ at $100 \mathrm{~V}$ through $1 \%$ agarose gel (Invitrogen). S. aureus reference strains were included in all reactions as positive control; ATCC 13565 (sea), ATCC 14458 (seb), ATCC 19095 (sec), ATCC 27664 (see), ATCC 51811 (seh), FRI 472 (sed, seg, sei, selj, selm, seln, selo, selr, selu).

\section{Identification of genes conferring resistance to fluoroquinolone}

The Quinolone resistance determining regions (QRDRs) of $g y r A, g y r B, g r l A, g r l B$ genes were investigated by PCR amplification using specific primer sequences [25, 26]. Each $20 \mu \mathrm{L}$ PCR reaction mixture contained: $10 \mu \mathrm{L}$ of $2 \mathrm{x}$ Taq Premix-Master mix, $6 \mu \mathrm{L}$ of sterile distilled water, 1 $\mu \mathrm{L}$ of forward primer, $1 \mu \mathrm{L}$ of reverse primer and $2 \mu \mathrm{l}$ of template DNA. PCR conditions for amplification of $\mathrm{grlA}$ and $\operatorname{grlB}$ genes: $95^{\circ} \mathrm{C}, 4 \mathrm{~min} ; 95^{\circ} \mathrm{C}, 1 \mathrm{~min} ; 48^{\circ} \mathrm{C}\left(52^{\circ} \mathrm{C}\right.$ for $\operatorname{grlB}), 1 \mathrm{~min} ; 72^{\circ} \mathrm{C}, 60 \mathrm{~s} ; 72^{\circ} \mathrm{C}, 4 \mathrm{~min}$; for $\operatorname{gyr} A: 95^{\circ} \mathrm{C}$, $1 \mathrm{~min} ; 95{ }^{\circ} \mathrm{C}$, $45 \mathrm{~s} ; 54{ }^{\circ} \mathrm{C}$, $60 \mathrm{~s} ; 72{ }^{\circ} \mathrm{C}, 1 \mathrm{~min}$; for gyrB: $94{ }^{\circ} \mathrm{C}, 2 \mathrm{~min} ; 94{ }^{\circ} \mathrm{C}, 1 \mathrm{~min} ; 48^{\circ} \mathrm{C}, 60 \mathrm{~s} ; 72{ }^{\circ} \mathrm{C}, 1 \mathrm{~min} ; 72^{\circ} \mathrm{C}$, 5 min.

\section{Detection of insertion sequence elements IS256 and IS257 among CoNS isolates}

Multiplex PCR assay was performed to identify insertion sequence elements IS256 and IS257, the appropriate oligonucleotide primers were selected as follows; for IS256 (762 bp), the $5^{\prime}$ primer AGTCCTTTTACGGTACAATG and the $3^{\prime}$ primer TGTGCGCATCAGAAATAACG; for IS257 (576 bp), the $5^{\prime}$ primer CTATCTAAGATATGC ATTGAG and the $3^{\prime}$ primer TTAACTTGCTAGCAT GATGC [17]. $25 \mu \mathrm{l}$ of PCR mixture contained $2 \mu \mathrm{L}$ of template DNA, $1 \mu \mathrm{l}$ of each primer for IS256 and IS257, $10 \mu \mathrm{L}$ of Master Mix, and $9 \mu \mathrm{L}$ of sterile distilled water. The PCR conditions included an initial denaturation at $94{ }^{\circ} \mathrm{C}$ for $3 \mathrm{~min}$, followed by amplification; 35 cycles at $94{ }^{\circ} \mathrm{C}$ for $1 \mathrm{~min}, 54^{\circ} \mathrm{C}$ for $1 \mathrm{~min}, 72^{\circ} \mathrm{C}$ for $2 \min$ and $72{ }^{\circ} \mathrm{C}$ for $5 \mathrm{~min}$.

\section{Statistical analysis}

Cramer's V, Phi- and Chi-square test were performed to assess of variables correlation. Phi and Cramer's V have ranges from 0 to 1 , where 1 indicates a significant association and 0 indicates no relationship. Interpretation of the Phi and Cramer's V results; $>0$; No or very weak, $>0.05$ weak; $>0.10$ moderate; $>0.15$ strong; $>0.25$ very strong. The Chi Square test was done by SPSS software version 20 . P value $<0.05$ was considered as statistically significant.

\section{Results}

\section{Isolation and prevalence of CoNS isolates}

Of the 91 clinical isolates of CoNS, 49 (53.8\%), 37 (40.7\%) and 5 (5.5\%) isolates were recognized as S. epidermidis, S. haemolyticus, and S. saprophyticus, respectively. Isolates were recovered from blood 39 (42.9\%), urine $33(36.3 \%)$, catheter $13(14.3 \%)$ and wound 6 $(6.6 \%)$.

\section{Antimicrobial susceptibility testing}

The results of antibiotic susceptibility testing of $91 \mathrm{CoNS}$ isolates and the distribution rate of SEs and TSST-1 toxins among antibiotic resistant strains are demonstrated in Table 2. Among CoNS species, the highest resistance was observed for cefoxitin (53.8\%), followed by trimethoprim-sulfamethoxazole $(46.2 \%, n=42)$ and none of the CoNS species was identified as being resistant to vancomycin. The highest percentage of genes that are involved in production of SEA, SEB, SEC, SEH, SEM, and TSST-1 toxins were significantly occurred among strains resistant to cefoxitin and trimethoprim-sulfamethoxazole with the frequencies of $100 \%, 100 \% ; 52 \%, 48 \% ; 63.6 \%, 50 \%$; $50 \%, 50 \% ; 80 \%, 60 \%$; and $56.5 \%, 47.8 \%$, respectively. In addition, among the phenotypically-resistant strains to cefoxitin and doxycycline, the distribution of SEE was significantly higher compared to strains resistant to other antibiotics (45.5\% and $27.3 \%$, respectively).

\section{Prevalence of Staphylococcal superantigen (SAg) genes among CoNS isolates}

The distribution of SEs and TSST-1 encoding genes among S. epidermidis, S. saprophyticus, and S. haemolyticus strains and in various clinical specimens are shown in Table 3. Our findings demonstrated the high frequency of SEs genes among isolated CoNS from blood cultures, followed by urine, catheter, and wound, respectively. The seg, sei, selj, selm, seln, selo, selk, sell, selp, selq, selr, selu genes were not detected in any of the isolates. The sec gene was the most frequent, which was detected in $48.4 \%$ of the isolates, followed by seb in $27.5 \%$, tsst in $25.3 \%$, see in $12.1 \%$, sem in $5.5 \%$, seh in $4.4 \%$, sed in $3.3 \%$, sea in $2.2 \%$. In the present study, enterotoxin-encoding genes were found in 39 (43\%) isolates, from which 17(46\%) belonged to S. epidermidis, 18(61\%) were S. haemolyticus and 4(80\%) S. saprophyticus strains were identified. Notably, the combinations of SEs genes were conserved in these strains. Amongst the positive isolates, 17 (53\%) were positive for two genes, 12 (31\%) were positive for three genes, and five (13\%) harbored four genes. The most common combination of enterotoxin-encoding genes was seb and sec, which found in $18.7 \%$ of isolates, 


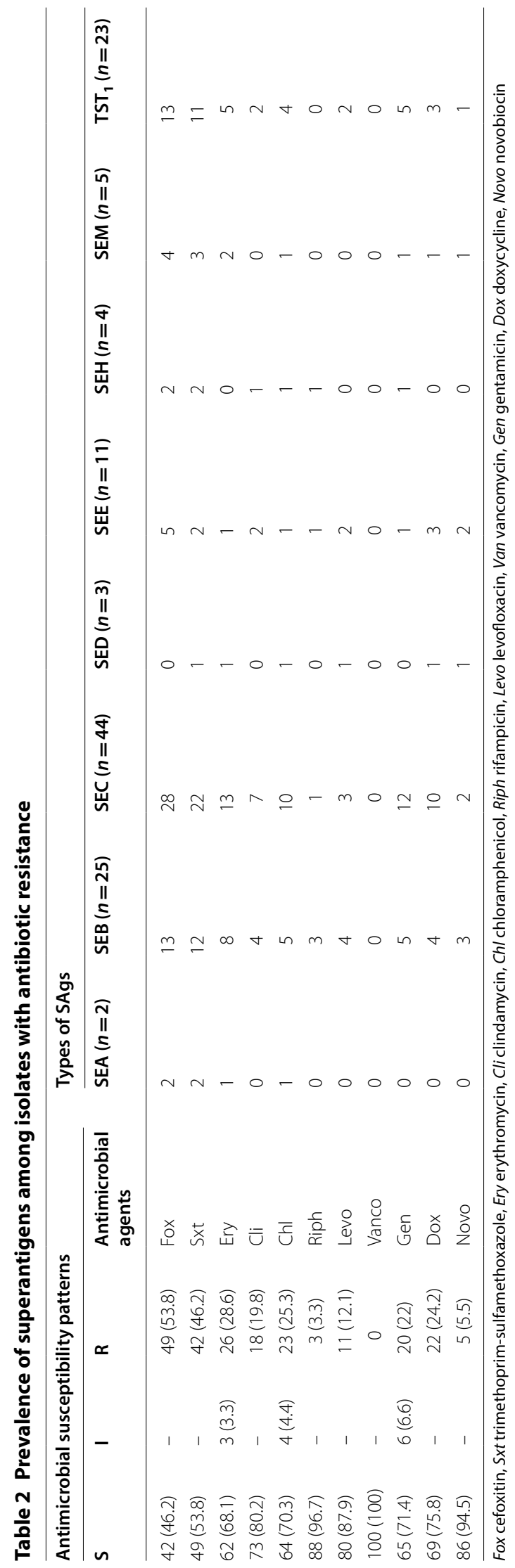


followed by $s e b+s e c+t s s t$ and $s e c+t s s t$ with frequencies of $15.6 \%$ and $12.5 \%$, respectively.

\section{The distribution of fluoroquinolone resistance genes among CoNS isolates}

The distribution pattern of antibiotic resistance genes among CoNS isolates and in various clinical specimens are presented in Table 4. The blood cultures had the highest number of strains carrying genes responsible for inducing resistance to levofloxacin, followed by catheter and urine. The genes conferring resistance to levofloxacin were found in any of the strains obtained from wound. Among 11 of the phenotypically levofloxacinresistant isolates, 9 isolates $(81.8 \%)$ with $g y r B, 8$ isolates (72.7\%) with $g y r A, 8$ isolates $(72.7 \%)$ with $g r l B$ and 7 isolates $(63.6 \%)$ with $g r l A$ were identified. The $g y r A$ and gyr $B$ genes were discovered as the most dominant genes inducing resistance to levofloxacin among $S$. saprophyticus strains and the $\operatorname{gyr} B$ and $\operatorname{grlB}$ genes were characterized with the highest frequency among $S$. haemolyticus strains.

\section{Prevalence of insertion sequence elements IS256} and IS257 among CoNS isolates

The distribution of IS256 and IS257 in the S. epidermidis, S. saprophyticus, and S. haemolyticus strains recovered from different sources are demonstrated in Table 5.

\section{Statistical analysis}

Considering the Antimicrobial susceptibility patterns, it was found a significant association between novobiocin resistance and the occurrence of sed and see genes ( $P=0.03, \phi=0.22$ and $P=0.04, \phi=0.21$, respectively),

Table 3 Prevalence of SEs and TSST ${ }_{1}$ encoding genes among various CoNS species and various clinical samples

\begin{tabular}{|c|c|c|c|c|c|c|c|c|}
\hline \multicolumn{5}{|l|}{ Source } & \multicolumn{4}{|l|}{ CoNS $(n=91)$} \\
\hline Catheter $n(\%)$ & Wound $n(\%)$ & Urine $n(\%)$ & Blood $n(\%)$ & $\begin{array}{l}\text { Super } \\
\text { antigenes }\end{array}$ & $\begin{array}{l}\text { S. epidermidis } \\
(n=49)\end{array}$ & $\begin{array}{l}\text { S. haemolyticus } \\
(n=37)\end{array}$ & $\begin{array}{l}\text { S. saprophyticus } \\
(n=5)\end{array}$ & Total $n(\%)$ \\
\hline $0(0)$ & $0(0)$ & $1(3)$ & $1(2.6)$ & SEA & $0(0)$ & $2(5.4)$ & $0(0)$ & $2(2.2)$ \\
\hline $4(30.8)$ & 1 (16.7) & $12(36.4)$ & $8(20.5)$ & SEB & $14(28.6)$ & 8 (21.6) & $3(60)$ & $25(27.5)$ \\
\hline $6(46.2)$ & $3(50)$ & $15(45.5)$ & $20(51.3)$ & SEC & $29(59.2)$ & $13(35.1)$ & $2(40)$ & $44(48.4)$ \\
\hline $0(0)$ & $0(0)$ & $2(6.1)$ & $1(2.6)$ & SED & $2(4.1)$ & $0(0)$ & $1(20)$ & $3(3.3)$ \\
\hline $1(7.7)$ & $0(0)$ & $8(24.2)$ & $2(5.1)$ & SEE & $7(14.3)$ & $2(5.4)$ & $2(40)$ & $11(12.1)$ \\
\hline $0(0)$ & $0(0)$ & $4(12.1)$ & $0(0)$ & SEH & $2(4.1)$ & $2(5.4)$ & $0(0)$ & $4(4.4)$ \\
\hline $0(0)$ & $0(0)$ & $2(6.1)$ & $3(7.7)$ & SEM & $2(4.1)$ & $2(5.4)$ & $1(20)$ & $5(5.5)$ \\
\hline $2(15.4)$ & $0(0)$ & $12(36.4)$ & $9(23.1)$ & $\mathrm{TST}_{1}$ & $14(28.6)$ & $8(21.6)$ & $1(20)$ & $23(25.3)$ \\
\hline
\end{tabular}

Table 4 Prevalence of fluoroquinolone resistance genes among various CoNS species and various clinical samples

\begin{tabular}{|c|c|c|c|c|c|c|c|c|}
\hline \multicolumn{5}{|l|}{ Source } & \multicolumn{4}{|l|}{ CoNS $(n=91)$} \\
\hline Catheter $n(\%)$ & Wound $n(\%)$ & Urine $n(\%)$ & Blood $n(\%)$ & $\begin{array}{l}\text { Resistance } \\
\text { genes }\end{array}$ & $\begin{array}{l}\text { S. epidermidis } \\
(n=5)\end{array}$ & $\begin{array}{l}\text { S. } \\
\text { haemolyticus } \\
(n=4)\end{array}$ & $\begin{array}{l}\text { S. } \\
\text { saprophyticus } \\
(n=2)\end{array}$ & Total n (\%) \\
\hline $2(100)$ & $0(0)$ & $2(100)$ & $4(57.1)$ & gyrA & $4(80)$ & $2(50)$ & $2(100)$ & $8(72.7)$ \\
\hline $2(100)$ & $0(0)$ & $2(100)$ & $5(71.4)$ & gyrB & $4(80)$ & $3(75)$ & $2(100)$ & $9(81.8)$ \\
\hline $2(100)$ & $0(0)$ & $0(0)$ & $5(71.4)$ & $g r \mid A$ & $4(80)$ & $2(50)$ & $1(50)$ & $7(63.6)$ \\
\hline $2(100)$ & $0(0)$ & $2(100)$ & $4(57.1)$ & $g r \mid B$ & $4(80)$ & $3(75)$ & $1(50)$ & $8(72.7)$ \\
\hline
\end{tabular}

Table 5 Prevalence of insertion sequences IS256 and IS257 among CoNS isolates and various clinical samples

\begin{tabular}{|c|c|c|c|c|c|c|c|c|}
\hline \multicolumn{5}{|l|}{ Source } & \multicolumn{4}{|l|}{ CoNS $(n=91)$} \\
\hline Wound $n(\%)$ & Catheter $n(\%)$ & Urine $n(\%)$ & Blood $n(\%)$ & Types of IS & $\begin{array}{l}\text { S. epidermidis } \\
(n=49)\end{array}$ & $\begin{array}{l}\text { S. haemolyticus } \\
(n=37)\end{array}$ & $\begin{array}{l}\text { S. saprophyticus } \\
(n=5)\end{array}$ & Total $n(\%)$ \\
\hline $2(6.9)$ & $2(6.9)$ & $12(41.4)$ & $13(44.8)$ & IS256 & $12(41.4)$ & $17(58.6)$ & $0(0)$ & $29(31.8)$ \\
\hline $3(4.4)$ & $11(16.2)$ & $24(35.3)$ & $30(44.1)$ & IS257 & $37(54.4)$ & $26(38.2)$ & $5(7.4)$ & $68(74.7)$ \\
\hline
\end{tabular}


gentamicin resistance and the presence of sec gene $(P=0.01, \phi=0.32)$ as well as between resistance to rifampicin and trimethoprim-sulfamethoxazole and the incidence of seh and see genes responsible for production the SEH and SEE enterotoxins was observed in current study ( $P=0.01, \phi=0.26$ and $P=0.04, \phi=0.21$, respectively). Among strains carrying insertion sequence elements found a significant association between the presence of IS256 and resistance to gentamicin as well as the occurrence of IS257 and resistance to cefoxitin ( $P=0.04, \phi=0.25$ and $\mathrm{P}=0.004, \phi=0.30$, respectively). In the current survey was also found meaningful relationship between the incidence of IS256 and production of SEA $(P=0.04, \phi=0.22)$.

\section{Discussion}

This study provides the first report of the frequency of SEs and TSST-1 encoding genes among human CoNS isolates in Iran. Some investigators have reported lack of enterotoxin genes associated with human and veterinary CoNS isolates $[27,28]$. The sec gene was the most common classic enterotoxin-encoding gene among all enterotoxin genes, which was detected in $48.4 \%$ of the isolates obtained from wound cultures. The frequency followed by $s e b$ and see, harbored by $27 \%$ and $12 \%$ of the isolates, respectively. While the sea, sed, seh and sem genes were rarely found $(2.2 \%, 3.2 \%, 4.4 \%$ and $5.4 \%$, respectively). The low prevalence of some SEs genes including sem in this study could be due to the theory that indicated enterotoxin-like (SEl) toxin genes are more abundant among commensal strains as compared to pathogenic ones [29]. Other studies also showed significantly higher rates of sec in CoNS isolated from coalho cheese, goat milk, industry meat and newborns, which ranged from $46.8 \%$ to $78 \%$ [5, 30-32]. Andrade et al. (2019) researched the occurrence of sea, seb, sec, sed, see, seg, seh, sei and sej genes in strains of Staphylococcus coagulase-positive (CoPS) and negative isolated from coalho cheese, and detected the presence of the following genes: seh (53.2\%) in CoPS strains and sec (46.8\%) in CoNS strains [30]. Lyra et al. (2013), also investigated SEs-encoding genes (sea, sec, sed, see, seg, seh, sei) in 44 strains of CoNS isolated from goat milk and found the presence of the $\mathrm{sec}$ in $55.6 \%$ of the strains and sea gene was found only in one strain [5]. These results indicate that the occurrence of the SEs genes isolated from coalho cheese and goat milk were not very diverse. Pinheiro et al. reported the presence of sea, seb, sec, sed, see, seg, seh and sei genes among S. epidermidis and S. haemolyticus isolated from blood cultures, while sei, seg and sea were the most frequent genes in both species [33]. It can relate to the fact that nosocomial isolates may be better equipped with virulence factors obtained by facilitated transfer through selective pressure. This is in contrast with other similar works which have been indicated the occurrence of sea gene in the higher frequency compared to other enterotoxin genes. Veras et al. evaluated the potential of CoNS and CoPS strains associated with outbreaks of staphylococcal food poisoning in Brazil and reported that enterotoxin genes were observed amongst $70 \%$ of the CoNS isolates. $38 \%$ found to harbor sea, $29 \%$ amplified only seb, and the concomitant presence of the sea and seb genes were reported in $24 \%$ of the isolates. Genes for sec and sed (either alone or concomitantly) were found infrequently [34]. In another study, the sea and $s e b$ genes have also described as the most common SEs gene among the staphylococcal species causing bovine mastitis [35]. These differences between studies may be related to geographic origin of the isolates, number and genetic structure of each isolate. In the current study, all of the strains producing of the enterotoxin SEA were positive for both sea and seb. The concomitant presence of these two genes in the same bacterium is explained by the fact that they occupy the same chromosome locus [36]. 17(46\%) and 11 (61\%) of toxigenic S. epidermidis and $S$. haemolyticus strains showed two or more the SEs genes in association that $s e b+s e c$ were detected as the most frequent. Other studies have also reported the concomitant presence of SEs genes in these organisms. Cunha et al. (2006) revealed the simultaneous presence of the seb and sec genes in 11\%, sea/seb and sea/seb/ sec in $5 \%$ of the CoNS obtained from newborns hospitalized in the Neonatal Unit of the Hospital of the Botucatu Medical School [32]. In another work, the concomitant incidence sea and seb genes have observed in $20 \%$ of the S. epidermidis and S. haemolyticus strains recovered from blood cultures [33]. The tsst gene was identified in $25 \%$ of CoNS species including $28.6 \%$ of $S$. epidermidis, $21.6 \%$ of S. haemolyticus and $20 \%$ of S. saprophyticus strains. In contrary with our work, other studies have found tsst gene in any of CoNS species isolated from newborns and cows with bovine mastitis [32, 37]. But this gene has been detected in $87 \%$ of $S$. aureus isolated from wound and blood cultures and in $15.5 \%$ of $S$. aureus obtained from bovine mastitis milk $[38,39]$. Our findings demonstrated a high percentage of toxigenic strains among $S$. epidermidis $(75.5 \%, n=37)$, followed by $S$. haemolyticus $(48.6 \%$, $n=18$ ). This is in accordance with other findings (Pinheiro et al. and Cunha et al.), which S. epidermidis was described as the CONS with the highest potential to produce of enterotoxins among identified isolates [33, 40]. The current study indicated a higher incidence of SEs genes among strains recovered from positive blood cultures $(42.3 \%)$, so that $55 \%$ and $38 \%$ of all S. haemolyticus and S. epidermidis strains contained at least one enterotoxin gene, predominating followed by urine (37.2\%), catheter (13.5\%) and wound (6.7\%) sources. This was in 
agreement with a similar survey carried out by Pinheiro et al. who exhibited a high prevalence of SEs genes in isolated S. epidermidis and S. haemolyticus strains from blood cultures with frequencies of $95.3 \%$ and $79.8 \%$, respectively [33]. This is likely due to the fact that genes encoding some virulence factors were up-regulated in human blood over time. The coordinated expression of diverse virulence factors during infections (e.g., expression of adhesins early during colonization versus production of toxins late in infection to facilitate tissue spread) hints at the existence of multiple regulatory elements that respond to a variety of different environmental signals [41-43]. Considering the antimicrobial susceptibility patterns, the highest resistance rates were determined for cefoxitin in $53.8 \%$ and trimethoprim-sulfamethoxazole in $46.2 \%$ of the isolates. The highest frequency of sea gene responsible for the synthesis of the SEA was detected among strains that exhibited phenotypic resistance to chloramphenicol, erythromycin, cefoxitin and trimethoprim-sulfamethoxazole antibiotics. The sec gene among strains that acquired resistant to gentamicin and sed in strains with phenotypic resistance to doxycycline, levofloxacin, novobiocin were the most abundant identified SEs genes. Clindamycin and rifampicin resistant strains showed higher frequencies of CoNS containing the seh gene in association with other SEs genes. In addition, in this regard, the largest frequency of see gene was found among isolates showing phenotypically resistance toward cefoxitin and doxycycline antibiotics and $18 \%$ of all CoNS isolates harbored see gene and exhibited resistance to trimethoprim-sulfamethoxazole, clindamycin, levofloxacin and novobiocin antibiotics concurrently. Regarding the results of statistical analysis in CoNS isolates observed a significant association between the incidence of SEs genes and resistance to antimicrobial agents. Schroeder et al, and Motamedi et al. described the role of the occurrence infective determinant-associated genes in the development of resistance to the antimicrobial agents and fatal Staphylococcal infections [44, 45]. 11 (12\%) Out of 91 isolates were found to be resistant to levofloxacin, which the most dominant detected CoNS species was $S$. epidermidis (46\%), followed by S. haemolyticus (36\%) and S. saprophyticus (18\%). The most remarkable percentage of the resistant isolates were found in the blood infections (64\%), followed by catheter-associated urinary tract infections (18\%). $45 \%$ of the identified isolates that exhibited phenotypic resistance to levofloxacin were carrying the SEs and TSST $_{1}$ genes that $s e b+\sec$ were the most frequent, and the majority of toxigenic strains of CoNS were shown to belong to $S$. haemolyticus. In this regard, our finding is similar to another study in which the proportion of resistance to levofloxacin ranged from $0 \%$ in methicillin-resistant S. haemolyticus (MRSH) to $7.7 \%$ in methicillin-resistant S. epidermidis (MRSE) strains [46]. These findings confirm which levofloxacin is a fluoroquinolone that exerts a potent effect against MRSH, MRSE and CoNS strains. It should be noted that, the access very little available literature on any information concerning the $\operatorname{gyr} A, \operatorname{gyrB}$, grlA, and $\operatorname{grlB}$ genes in staphylococci isolates was available. Among the phenotypically-resistant strains to levofloxacin, 5 (45.4\%) out of 11 isolates determined to be positive for carrying of levofloxacin-conferring genes. Notably, the combinations of resistance genes were conserved in these strains. Amongst the positive isolates, $6(54.5 \%)$ were positive for four genes, $3(27.2 \%)$ were positive for three genes and 1 (9\%) harbored two genes. In levofloxacin-resistant $S$. haemolyticus strains the $\operatorname{grl} A+\operatorname{grl} B$ and $\operatorname{gyr} B$ genes were responsible for inducing resistance to levofloxacin. In a survey carried out by Osman et al., gyrA, gyrB and $g r l A$ genes in $S$. haemolyticus strains were absent and $66.6 \%$ and $33.33 \%$ of MSSA (methicillin susceptible Staphylococcus aureus) isolates carried $g y r A$ and $g y r B$ genes, which in contrary to our results the prevalence percentage of these genes were reported with high incidence, $50 \%, 75 \%$ and $50 \%$, respectively [1]. According to published results by Osman et al., the prevalence of $g y r A$ and $g r l A$ genes among various staphylococcus species in accordance with our results were with high incidence (63\% and $70.4 \%$, respectively) and $\operatorname{gyr} B$ gene in contrary with our findings was identified with incidence low, 26\% [47]. Fluoroquinolones (FQs) are categorized as effective antibiotics against a wide variety of organisms and having a role in the chemotherapy and postexposure prophylaxis for organisms, that could be used in biologic warfare. A extreme resistance could be attributed to the extensive use of FQs which can led to the development of drug resistance among staphylococcus isolates and other bacterial species [47]. Regarding to the prevalence proportion of insertion sequences, IS256 and IS257 were identified with the highest frequency among S. haemolyticus and S. epidermidis strains with the frequencies of $58.6 \%, 41.4 \%$ and $38.2 \%, 54.4 \%$, respectively. Studies analyzing the prevalence rate of IS256 among S. epidermidis strains have been reported diverging results from $46.7 \%$ to $81 \%$ [ 48 50]. Previous reports have demonstrated that IS256 is significantly associated with multi-resistant, biofilmforming S. epidermidis isolates resident in the hospital setting [51]. It was also indicated association of the IS256 with the genomes of aminoglycoside-resistant staphylococci and enterococci isolates [52, 53]. In addition, in this study statistically found significant association between the incidence of IS256 and resistance to gentamicin as well as between the presence of IS257 and resistance to cefoxitin ( $p$ value 0.033 and 0.004 , respectively). The IS257 is a mobile genetic element, which associated with 
genes mediating biofilm formation and genes conferring resistance to beta-lactamase, aminoglycosides and tetracycline antibiotics $[54,55]$. The IS 256 can be used as a potential molecular marker to discriminate invasive strains from commensal strains of S. epidermidis [56]. Montanaro et al. demonstrated a dramatic correlation between the presence of IS256 and resistance to gentamicin [57]. Considering the antimicrobial susceptibility patterns, strains harboring IS256 and IS257 were the most frequent among those with resistance to cefoxitin (53\% and $76 \%$, respectively). It was also found that IS256 may influence the expression of pathogenesis-related genes [50]. In current research IS256 was the most common among isolates harboring sea also statistically found significant relationship between production of SEA and the occurrence of IS256.

\section{Limitations}

One of the limitation of this study was evaluation of the expression level of genes responsible for production of superantigens and antibiotic resistance-inducing genes and also the sample size, if we could include higher the sample sizes in our research we would definitely get better and more reliable results.

\section{Conclusion}

The high prevalence of SEs-encoding genes indicating a potential risk for causing human-originated food poisoning and also the emergence of multidrug-resistant bacteria is a serious problem for public health. Due to the correlation between the incidence of SAgs and the patterns of antibiotic resistance in CoNS isolates, therefore, detection of isolates harboring toxin genes associated with antibiotic resistance is rapidly becoming a significant issue of concern. The high degree of coexistence of resistance to cefoxitin and the presence of IS257 among different CoNS species indicates their role in infectious diseases. In addition, correlation between the incidence of insertion element IS256 and production of SEA enterotoxin as well as resistance toward gentamicin conferring selective advantage for pathogenesis and survival of invasive CoNS isolates in hospital settings.

\section{Abbreviations \\ CoNS: Coagulase-negative staphylococci; SAgs: Superantigens; SFP: Staphy- lococcal food poisoning; ETs: Exfoliative toxins; TSST-1: Toxic shock syndrome toxin 1; PTSAgs: Pyrogenic toxin superantigen family of exotoxins; QRDRs: Quinolone resistance determining regions; DAD: Disk agar diffusion; CLSI: Clinical and Laboratory Standards Institute.}

\section{Acknowledgements}

The authors of this article are grateful to Hamadan University of Medical Sciences for their financial support in conducting research. This work was supported by the vice chancellor and Research technology of Hamadan University of Medical Sciences on the grant number, 9612087936.

\section{Authors' contributions}

MN and ZS performed the tests, collected and analyzed the data, performed the analysis of the data. HT and SD contributed in design and project adminstration. MRA designed the project and contributes in the whole steps of the projects. All authors read and approved the final manuscript.

\section{Funding}

The Research and technology of Vice Chancellor of Hamadan University of Medical Sciences (Project Number: 9612087936).

\section{Availability of supporting data}

The datasets used and/or analyzed during the current study are available from the corresponding author on reasonable request.

\section{Ethical approval and consent to participate}

This study was approved by the ethics committee of the Hamadan University of Medical Sciences ((Code No: IR.UMSHA.REC.1396.827)) and about the consent to participate is not applicable.

\section{Consent for publication}

Not applicable.

\section{Competing interests}

The authors declare that they have no competing interests.

\section{Author details}

${ }^{1}$ Department of Microbiology, Faculty of Medicine, Hamadan University of Medical Sciences, Shahid Fahmideh Street, Park Mardome, Hamadan, IR, Iran. ${ }^{2}$ School of Medicine, Shahroud University of Medical Sciences, Shahroud, Iran. ${ }^{3}$ Nutrition Research Center, Hamadan University of Medical Sciences, Hamadan, IR, Iran.

Received: 4 February 2020 Accepted: 25 September 2020

Published online: 12 October 2020

\section{References}

1. Osman K, Alvarez-Ordóñez A, Ruiz L, Badr J, ElHofy F, Al-Maary KS, et al. Antimicrobial resistance and virulence characterization of Staphylococcus aureus and coagulase-negative staphylococci from imported beef meat. Ann Clin Microbiol Antimicrob. 2017;16(1):35.

2. Wang Y-T, Lin Y-T, Wan T-W, Wang D-Y, Lin H-Y, Lin C-Y, et al. Distribution of antibiotic resistance genes among Staphylococcus species isolated from ready-to-eat foods. J Food Drug Anal. 2019;27(4):841-8.

3. Xu Z, Shah HN, Misra R, Chen J, Zhang W, Liu Y, et al. The prevalence, antibiotic resistance and mecA characterization of coagulase negative staphylococci recovered from non-healthcare settings in London, UK. Antimicrob Resist Infect Control. 2018;7(1):73.

4. Xie Y, He Y, Gehring A, Hu Y, Li Q, Tu S-I, et al. Genotypes and toxin gene profiles of Staphylococcus aureus clinical isolates from China. PLoS ONE. 2011;6(12):e28276.

5. Lyra DG, Sousa FG, Borges MF, Givisiez PE, Queiroga RC, Souza EL, et al. Enterotoxin-encoding genes in Staphylococcus spp. from bulk goat milk. Foodborne Pathogens Dis. 2013;10(2):126-30.

6. Bianchi DM, Gallina S, Bellio A, Chiesa F, Civera T, Decastelli L. Enterotoxin gene profiles of $S$ taphylococcus aureus isolated from milk and dairy products in I taly. Lett Appl Microbiol. 2014;58(2):190-6.

7. Nazari R, Godarzi H, Baghi FR, Moeinrad M. Enterotoxin gene profiles among Staphylococcus aureus isolated from raw milk. Iran J Vet Res. 2014;15(4):409.

8. Leke A, Goudjil S, Mullie C, Grognet S, Biendo M. PCR detection of staphylococcal enterotoxin genes and exfoliative toxin genes in methicillinresistant and methicillin-susceptible Staphylococcus aureus strains from raw human breast milk. Clin Nutr Exp. 2017;14:26-35.

9. Mansour AS, Wagih GE-S, Morgan SD, Elhariri M, El-Shabrawy MA, Abuelnaga AS, et al. Detection of Staphylococcus aureus enterotoxigenic strains in bovine raw milk by reversed passive latex agglutination and multiplex polymerase chain reaction. Veterinary world. 2017;10(8):843. 
10. Chen Q, Xie S. Genotypes, enterotoxin gene profiles, and antimicrobial resistance of Staphylococcus aureus associated with foodborne outbreaks in Hangzhou, China. Toxins. 2019;11(6):307.

11. Bertelloni F, Fratini F, Ebani WV, Galiero A, Turchi B, Cerri D. Detection of genes encoding for enterotoxins, TSST-1, and biofilm production in coagulase-negative staphylococci from bovine bulk tank milk. Dairy Sci Technol. 2015;95(3):341-52.

12. Rajabi M, Abdar ME, Rafiei H, Aflatoonia MR, Abdar ZE. Nosocomial infections and epidemiology of antibiotic resistance in teaching hospitals in south east of Iran. Glob J Health Sci. 2016;8(2):190.

13. Bora P, Datta P, Gupta V, Singhal L, Chander J. Characterization and antimicrobial susceptibility of coagulase-negative staphylococci isolated from clinical samples. J Lab Physicians. 2018;10(4):414.

14. Redgrave LS, Sutton SB, Webber MA, Piddock LJ. Fluoroquinolone resistance: mechanisms, impact on bacteria, and role in evolutionary success. Trends Microbiol. 2014;22(8):438-45.

15. Hooper DC. Fluoroquinolone resistance among Gram-positive cocci. Lancet Infect Dis. 2002;2(9):530-8.

16. Yamada M, Yoshida J, Hatou S, Yoshida T, Minagawa Y. Mutations in the quinolone resistance determining region in Staphylococcus epidermidis recovered from conjunctiva and their association with susceptibility to various fluoroquinolones. Br J Ophthalmol. 2008;92(6):848-51.

17. Chessa D, Ganau G, Spiga L, Bulla A, Mazzarello V, Campus GV, et al. Staphylococcus aureus and Staphylococcus epidermidis virulence strains as causative agents of persistent infections in breast implants. PLOS ONE. 2016;11(1):e0146668.

18. Murphy RJ, Lee YT, Pang S, Bastholm TR, Crow JE, Davis AM, et al. Complete genome sequence of a Staphylococcus aureus sequence type 612 isolate from an Australian horse. Microbiol Resour Announc. 2018;7(4):e00869-918.

19. Mozafarianari A, Kariminik A, Tashakori M. Evaluation of the frequency of enterotoxin A (SEA) and enterotoxin B (SEB) genes in clinical isolates of Staphylococcus aureus in Rafsanjan, Iran. Avicenna J Clin Microbiol Infect. 2019;6(4):118-21.

20. Junior JCR, Tamanini R, Soares BF, de Oliveira AM, de Godoi Silva F, da Silva $F F$, et al. Efficiency of boiling and four other methods for genomic DNA extraction of deteriorating spore-forming bacteria from milk. Semina Ciências Agrárias. 2016;37(5):3069-78.

21. Hecht DW, Citron DM, Cox M, Jacobus N, Jenkins S, Onderdonk A, et al. Methods for antimicrobial susceptibiluty testing of anaerobic bacteria: approved standard. Wayne: Clin Lab Standards Inst; 2007.

22. Blaiotta G, Ercolini D, Pennacchia C, Fusco V, Casaburi A, Pepe O, et al. PCR detection of staphylococcal enterotoxin genes in Staphylococcus spp. strains isolated from meat and dairy products Evidence for new variants of seG and sel in S. aureus AB-8802. J Appl Microbiol. 2004;97(4):719-30.

23. Omoe K, Hu D-L, Takahashi-Omoe H, Nakane A, Shinagawa K. Comprehensive analysis of classical and newly described staphylococcal superantigenic toxin genes in Staphylococcus aureus isolates. FEMS Microbiol Lett. 2005;246(2):191-8.

24. Nunes RSC, de Souza CP, Pereira KS, Del Aguila EM, Paschoalin VMF. Identification and molecular phylogeny of coagulase-negative staphylococci isolates from Minas Frescal cheese in southeastern Brazil: superantigenic toxin production and antibiotic resistance. J Dairy Sci. 2016;99(4):2641-53.

25. Osman K, Badr J, Al-Maary KS, Moussa IM, Hessain AM, Girah Z, et al. Prevalence of the antibiotic resistance genes in coagulase-positive-and negative-Staphylococcus in chicken meat retailed to consumers. Front Microbiol. 2016;7:1846.

26. Linde $\mathrm{H}-\mathrm{J}$, Schmidt M, Fuchs $\mathrm{E}$, Reischl U, Niller $\mathrm{H}-\mathrm{H}$, Lehn N. In vitro activities of six quinolones and mechanisms of resistance in Staphylococcus aureus and coagulase-negative staphylococci. Antimicrob Agents Chemother. 2001;45(5):1553-7.

27. Nemati M, Hermans K, Vancraeynest D, De Vliegher S, Sampimon O, Baele $\mathrm{M}$, et al. Screening of bovine coagulase-negative staphylococci from milk for superantigen-encoding genes. Vet Rec. 2008;163(25):740-3.

28. Park JY, Fox LK, Seo KS, McGuire MA, Park YH, Rurangirwa FR, et al. Detection of classical and newly described staphylococcal superantigen genes in coagulase-negative staphylococci isolated from bovine intramammary infections. Vet Microbiol. 2011;147(1-2):149-54.

29. Rahimi F, Shokoohizadeh L. Characterization of virulence factors and prophage profiles of methicillin-resistant Staphylococcus aureus strains isolated from a referral hospital in Tehran, Iran. Archiv Clin Infect Dis. 2018;13(5).

30. Andrade AD, Borges M, De Figueiredo EAT, Arcuri EF. Diversity of Staphylococcus coagulase: positive and negative strains of coalho cheese and detection of enterotoxin encoding genes. Embrapa Agroindústria Tropical-Artigo em periódico indexado (ALICE). 2019.

31. Soares Casaes Nunes R, Mere Del Aguila E, Paschoalin VMF. Safety evaluation of the coagulase-negative staphylococci microbiota of salami: superantigenic toxin production and antimicrobial resistance. BioMed Res Int. 2015;2015:483548. https://doi.org/10.1155/2015/483548.

32. Cunha MDLRDSD, Rugolo LMSDS, Lopes CADM. Study of virulence factors in coagulase-negative staphylococci isolated from newborns. Memórias do Instituto Oswaldo Cruz. 2006;101(6):661-8.

33. Pinheiro L, Brito Cl, De Oliveira A, Martins PYF, Pereira VC, Da Cunha MDLRDS. Staphylococcus epidermidis and Staphylococcus haemolyticus: molecular detection of cytotoxin and enterotoxin genes. Toxins. 2015;7(9):3688-99.

34. Veras JF, do Carmo LS, Tong LC, Shupp JW, Cummings C, dos Santos DA, et al. A study of the enterotoxigenicity of coagulase-negative and coagulase-positive staphylococcal isolates from food poisoning outbreaks in Minas Gerais, Brazil. Int J Infect Dis. 2008;12(4):410-5.

35. de Freitas Guimarães F, Nóbrega DB, Richini-Pereira VB, Marson PM, de Figueiredo Pantoja JC, Langoni H. Enterotoxin genes in coagulasenegative and coagulase-positive staphylococci isolated from bovine milk. J Dairy Sci. 2013;96(5):2866-72.

36. Jett M, Das R, Neill R. The staphylococcal enterotoxins. Molecular medical microbiology: Elsevier; 2002. p. 1089-116

37. Mello PL, Moraes Riboli DF, Pinheiro L, de Almeida Martins L, Vasconcelos Paiva Brito MA, da Cunha RDS, et al. Detection of enterotoxigenic potential and determination of clonal profile in Staphylococcus aureus and coagulase-negative staphylococci isolated from bovine subclinical mastitis in different Brazilian states. Toxins. 2016;8(4):104.

38. Koosha RZ, Hosseini HM, Aghdam EM, Tajandareh SG, Fooladi AAI. Distribution of tsst-1 and mecA genes in Staphylococcus aureus isolated from clinical specimens. Jundishapur J Microbiol. 2016;9(3).

39. Farahmand AS, Ahmadi M, Dastmalchi SH, Anassori E. Identification of Toxic Shock Syndrome Toxin-1 (TSST-1) gene in Staphylococcus aureus isolated from bovine mastitis milk. Arch Razi Inst. 2013;68(1):17-22. https://doi.org/10.7508/ARI.2013.01.003.

40. de Lourdes RS, da Cunha M, Calsolari RA, Júnior JPA. Detection of enterotoxin and toxic shock syndrome toxin 1 genes in Staphylococcus, with emphasis on coagulase-negative staphylococci. Microbiol Immunol. 2007;51(4):381-90.

41. Fisher EL, Otto M, Cheung GY. Basis of virulence in enterotoxin-mediated staphylococcal food poisoning. Front Microbiol. 2018;9:436.

42. Malachowa N, Whitney AR, Kobayashi SD, Sturdevant DE, Kennedy AD, Braughton KR, et al. Global changes in Staphylococcus aureus gene expression in human blood. PLoS ONE. 2011;6(4):e18617.

43. Bien J, Sokolova O, Bozko P. Characterization of virulence factors of Staphylococcus aureus: novel function of known virulence factors that are implicated in activation of airway epithelial proinflammatory response. J Pathog. 2011;2011:601905. https://doi. org/10.4061/2011/601905.

44. Schroeder M, Brooks BD, Brooks AE. The complex relationship between virulence and antibiotic resistance. Genes. 2017:8(1):39.

45. Motamedi H, Asghari B, Tahmasebi H, Arabestani MR. Identification of hemolysine genes and their association with antimicrobial resistance pattern among clinical isolates of Staphylococcus aureus in West of Iran. Adv Biomed Res. 2018;7.

46. Cafiso V, Messina C, Santagati M, Campanile F, Bonfiglio G, Stefani S. In vitro activity of levofloxacin against coagulase-positive and-negative Staphylococci. Drugs Exp Clin Res. 2001;27(3):107-12.

47. Osman KM, Amer AM, Badr JM, Helmy NM, Elhelw RA, Orabi A, et al. Antimicrobial resistance, biofilm formation and mecA characterization of methicillin-susceptible S. aureus and non-S. aureus of beef meat origin in Egypt. Front Microbiol. 2016;7:222.

48. Diemond-Hernández B, Solórzano-Santos F, Leaños-Miranda B, Peregrino-Bejarano L, Miranda-Novales G. Production of icaADBC-encoded polysaccharide intercellular adhesin and therapeutic failure in pediatric patients with staphylococcal device-related infections. BMC Infect Dis. 2010;10(1):68. 
49. Rahimi F, Karimi S. Biofilm Producing Staphylococcus epidermidis strains isolated from clinical samples in Tehran, Iran. Archiv Clin Infect Dis. 2016;11(3).

50. Koskela A, Nilsdotter-Augustinsson Å, Persson L, Söderquist B. Prevalence of the ica operon and insertion sequence IS256 among Staphylococcus epidermidis prosthetic joint infection isolates. Eur J Clin Microbiol Infect Dis. 2009;28(6):655-60.

51. Kozitskaya S, Cho S-H, Dietrich K, Marre R, Naber K, Ziebuhr W. The bacterial insertion sequence element IS256 occurs preferentially in nosocomial Staphylococcus epidermidis isolates: association with biofilm formation and resistance to aminoglycosides. Infect Immun. 2004;72(2):1210-5.

52. Dyke K, Aubert S, El Solh N. Multiple copies of IS256 in staphylococci. Plasmid. 1992;28(3):235-46.

53. Rice LB, Thorisdottir AS. The prevalence of sequences homologous to IS256 in clinical enterococcal isolates. Plasmid. 1994;32(3):344-9.

54. Dutta TK, Chakraborty S, Das M, Mandakini R. Multidrug-resistant Staphylococcus pettenkoferi isolated from cat in India. Vet World. 2018;11(10):1380.
55. Tuchscherr LP, Gomez M, Buzzola FR, Calvinho LF, Lee J, Sordelli DO. Characterization of a new variant of IS257 that has displaced the capsule genes within bovine isolates of Staphylococcus aureus. Infect Immun. 2007;75(11):5483-8.

56. Gu J, Li H, Li M, Vuong C, Otto M, Wen Y, et al. Bacterial insertion sequence IS256 as a potential molecular marker to discriminate invasive strains from commensal strains of Staphylococcus epidermidis. J Hosp Infect. 2005;61(4):342-8

57. Montanaro L, Campoccia D, Pirini V, Ravaioli S, Otto M, Arciola CR. Antibiotic multiresistance strictly associated with IS256 and ica genes in Staphylococcus epidermidis strains from implant orthopedic infections. J Biomed Mater Res Part A. 2007:83(3):813-8.

\section{Publisher's Note}

Springer Nature remains neutral with regard to jurisdictional claims in published maps and institutional affiliations.
Ready to submit your research? Choose BMC and benefit from:

- fast, convenient online submission

- thorough peer review by experienced researchers in your field

- rapid publication on acceptance

- support for research data, including large and complex data types

- gold Open Access which fosters wider collaboration and increased citations

- maximum visibility for your research: over $100 \mathrm{M}$ website views per year

At BMC, research is always in progress.

Learn more biomedcentral.com/submissions 